To get a fair comparative view of the Harrisburg achievement it might be well to note that to parallel it the city of New York would have had to spend upon the unselfish subject of expert advice for municipal beterment, $\$ 975,000$, to guide a municipal expenditure in complete efficiency of approximately $\$ 320,000,000$.

Or, to do as well, Philadelphia would have had to pave with complete efficiency about 1,400 miles of streets, provide 18,000 acres of parks, improve with parking and protection all its river front, both of the Schuylkill and the Delaware, change its lighting, and efficiently filter all its water-and all without even a suspicion of graft!

That Harrisburg does not intend to stop was well shown in the forward vision of Hon. Vance C. McCormick, at the celebration. ${ }^{3}$ He drew a fascinating picture of what the city might do and probably would do, and the enthusiasm of the people upon finding that municipal expenditures of this sort are actually investments is likely to make his dreams come true.

\title{
THE SUNDAY QUESTION IN CHICAGO
}

\author{
BY VICTOR S. YARROS ${ }^{1}$ \\ Chicago
}

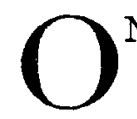

NCE more Chicago is wrestling with the eternal Sunday questionby which, of course, is meant the question of Sunday liquor selling. It has a certain periodicity; it has come up every five years or so, but Mayor Thompson's recent coup d'etat has introduced dramatic variety into the familiar comedy. His action was like the proverbial bolt from the blue sky. It was a startling surprise to the whole community, and apparently even to some of his close political friends. Everybody is still wondering and asking what his motives were and under what compulsion he acted as he did. Many are wondering also how long this act of the comedy will last, and whether there is soon to be a mayoral order, or wink, or nod, that will bring the curtain down and announce another act.

But the better to understand the present queer situation it is necessary to summarize the earlier parts of the story.

Legally speaking, Chicago has no special Sunday saloon question. The Sunday closing law is state-wide, is in full force "on paper," and

"Former Mayor McCormick in his speech on this occasion said: "I wish I could enumerate to you from my own personal experience the names of those faithful citizens to whom honor is due, but if there is one man above others who stands out pre-eminently as a patriot in all these years of improvement campaigns, it is J. Horace McFarland, the creator of our park system, and who, to my mind, has done more than any other man for the parks and public improvements of Harrisburg." Editor.

${ }^{1}$ See National Municipal Review, vol. iv, p. 448. 
makes no distinctions or exceptions. If the saloons have been open in Chicago and a few other Illinois cities on Sunday, and closed everywhere else in the state, the reasons for the discrepancy are found in the facts of life. In Chicago it has been, for over forty years, deemed "impossible" to enforce the Sunday closing law. The cosmopolitan character of the city's population; the size of the city and the number of its subdivisions and foreign "colonies"; the influence of the Germans and other citizens of European traditions with reference to Sunday amusements and recreations; the organization of "the United Societies" of hyphenated Americans for the purpose of defending "personal liberty" and local autonomy, and of defeating "dry" candidates for local or state offices--these and other factors account for the fact that the Sunday closing law has been a "dead letter" in Chicago.

Few aldermanic candidates and no mayoral candidate (except the avowed Prohibition candidates) could be induced expressly and definitely to promise, even before an election in which the Sunday law was made an issue by certain embattled groups, to enforce that law or to breathe life into it. Sincere, aggressively honest and intelligent men like Professor Merriam have, as candidates for mayor, either avoided that issue or frankly told the voters that it was not their intention to shake the dust off the Sunday law and try to enforce it regardless of popular sentiment, or the pendency of other and more vital issues, just because "it is law." The newspapers of the city, as a rule, have discouraged the Sunday law feature of local political campaigns and approved of the passive or the hostile attitude of the candidates. Occasionally a newspaper changed its position between campaigns; but when vital and important issues were being fought out-issues like public utility regulation, compensation for franchises, etc.-the press ignored the Sunday question or even boldly advises the candidates to tell the people that the saloons would be left severely--or genially-alone.

It is merely stating a fact to say that heretofore the progressive and broad-minded citizens of Chicago have taken little interest in the Sunday question. They have realized that it meant political suicide for any mayoral candidate to pledge himself to enforce that unpopular statute. They have not cared to invite candidates to commit suicide. They have had work to do, or to get done, which demanded the serious attention of the mayor, the council, and the public.

But latterly there have appeared indications that the Sunday question was entering upon a new phase. For example, Professor Merriam, as a member of the city council, has urged legislation which the liquor and saloon interests have regarded as being deliberately unfriendly. His wife has personally investigated various low-grade dives and dance halls and has furnished proof of the fact that many of the saloon keepers will not obey even elementary regulations designed to protect the young, to 
impose external decency and to restrain commercial vice. Professor Merriam wants the liquor interests to refrain from meddling perniciously and destructively with municipal politics. He has proposed a certain tentative classification of saloons and suitable regulation for each class. Other aldermen of independence and creditable records have declared war on the law-violating saloons for other reasons or from other motives. In short, the atmosphere was changing. A few hotels recognized this and closed their bars on Sunday at the demand of the Prohibitionist or Sunday-closing crusaders. The steady advance of prohibition in the country at large has been a factor of considerable influence, no doubt, especially with impressionable aldermen. And if a few convictions for violation of the Sunday closing law had at last been secured, it can hardly be doubted that public prosecutors, mayors and aldermen would have come to regard their respective duties in the premises in a new light.

So far, however, it has been impossible to secure any convictions. Juries in Sunday saloon cases have either disagreed or else have returned verdicts of acquittal, and this in spite of explicit instructions from the Bench, the clearness and completeness of the evidence submitted by the prosecution, or the manifest legal weakness of the case of the defence. Juries have maintained this attitude simply and humanly because they know that in Chicago the Sunday closing law had long been honored in the breach rather than in the observance. They have regarded attacks on particular offenders as unfair, spiteful and unreasonable. Several years ago a firm, if narrow-minded, state's attorney persevered and tried case after case; but not a single conviction was he able to secure.

The Prohibitionists and the advocates of "law enforcement" have also vainly tried other methods-for instance, they have sought to obtain a writ of mandamus against the mayor compelling him to close the saloons on Sunday. The highest courts of the state have decided, however, that mandamus will not issue in such a case, and their reasoning has been approved by the fair-minded and informed lawyers. There has repeatedly been talk of an effort to impeach or indict the mayor of Chicago for failure to perform his sworn duty and enforce the law as it stands. This talk, when indulged in against a "radical" mayor like Dunne, was regarded as insincere and reaction-inspired. Certain privileged interests were believed to have conceived the idea of using the Sunday issue as a club, or, at least, as a means of diverting and confusing the public mind. When the same threat was renewed against Mayor Thompson, whom no sensible person regards either as a civic reformer or as a competent, consistent and vigorous administrator, it was not taken seriously by anybody; the "interests" were with the dashing, impulsive, boyish mayor, and neither impeachment nor indictment proceedings, had they really been attempted and pushed, would have had the slightest chance of a successful issue. 
Hence it is literally true that no one expected the mayor to pay any attention to the agitation or the threats of the dry leaders or the advocates of law enforcement "because it is law." Not a single editorial appeared in the Chicago daily press advising the mayor to close the Sunday saloons. Even though the conditions, as stated above, were undergoing a change, none of the neutrals thought the time was ripe for such an order from the mayor, and certainly none thought that the particular gentlemen who calls himself "Big Bill," who was known as a "sport" and friend of the sporting fraternity, who was elected largely on the sham "Prosperity" issue, and who loves parades, displays, proclamations and pomp, would suddenly issue such an order.

However, the order came. It was an order which, if the mayor "meant business," had to be obeyed. It was not an order to arrest offending saloonkeepers and start the judicial mill grinding. Such an order would have caused little alarm. But under our code the mayor has the power to revoke licenses for cause, and the deliberate violation of a state law would naturally be treated as ample and sufficient cause for revocation of licenses.

Why did Mayor Thompson issue the order? His own explanations are rather mixed and contradictory. In the first place he took the bold and virtuous or heroic line: He had been informed by the corporation counsel, his legal adviser, that the Sunday anti-saloon law was valid and binding, and that left him without an alternative. His own affiliations and habits, his own views concerning Sunday, his own desires and preferences, were irrelevant and immaterial. He was mayor; he had taken an oath to obey and enforce the laws-all laws-and he could not make an exception of the Sunday law. Now, if Mayor Thompson had only stuck to this explanation, his position would have been plausible enough. True, few would have believed his protestations; he would have been charged with political ambition, with vindictiveness-for the wets are said to have contributed but little to his campaign fund and to have spoken slightingly of his chances-with spectacularism and love of notoriety and sensations. Still, officially and formally the position would have appeared unassailable.

Unfortunately, the heroic attitude was too unnatural and trying for the mayor. He too soon offered further and different explanations-he had heard that his enemies were seeking to procure his indictment by the grand jury; he had heard that the foreman of a grand jury was privately conferring with prohibition and law-enforcement leaders; he did not care to face indictments and trials. A touch of opera-bouffe was added by his reported remark that the Christian Scientists had been praying for him and for the enforcement of the Sunday law.

Furthermore, when the united societies for local self-government, or the wets gave out a copy of the pre-election pledge signed by $\mathrm{Mr}$. Thomp- 
son-a pledge against Sunday law enforcement which was too explicit an evasion-proof even for far more artful dodgers, the mayor floundered badly. He had "forgotten" the pledge incident; he could not tell whether the signature was genuine without carefully examining it; at any rate, the pledge was merely "personal, not official"-as if a promise to veto certain ordinances and disregard certain laws could be made by a candidate for office in a "personal" capacity, and as if anybody would ever care to obtain personal pledges from otherwise important men in such circumstances.

In a word, the more the mayor talked, the more his enemies, old and new, rejoiced. Even those who approve of his action are pained and embarrassed by his maladroit and tactless utterances. Only some of the aggressive Prohibitionists are lauding the mayor and predicting great things for him. The average observer is distinctly contemptuous. Nothing will surprise him, for his faith in the mayor is weak, if not a negative quantity. The mayor is not enforcing "all laws." His appointees are emasculating the city civil service law. He is opposing budget reform and resisting attempts of the city council at investigation of certain city departments. Nothing about his "policies" is calculated to inspire the least confidence or respect.

Very typical, for instance, are these comments of Chief Justice Olson of the Chicago municipal court:

The situation is getting somewhat mixed, evidently. It reminds me of the old days, when our Sunday school teacher seemed to take great satisfaction in bringing in reformed gamblers and drunkards to tell us "kids" how to live. We winked at each other and saw the humor of the situation, and I now know that the "kids" had the situation sized up correctly. We always took more seriously the advice of men who had always lived right rather than in talks of the men who had sown their wild oats.

In these days of mixed politics the "old soaks" are going "dry" and the "drys" are going after the "old soaks." But it won't last long. We will soon sober up and be for the fellow who, as the girl says in the play, "is a regular fellow."

The future, therefore, is uncertain. There will be much fighting and political scheming and plotting in and out of the legislature, and the situation is bound to get more and more mixed before it begins to clear up. We are to have a sort or referendum on the dry and wet issue in Chicago. A direct referendum on Sunday closing is apparently impossible, for how can you submit, at public expense and under public authority, the question whether a state law held by the courts to be valid and live is or is not to be obeyed by mayors and other local executives? "Home rule" with regard to Sunday, a measure generally advocated by reasonable men, the legislature is not likely to grant in the near future. 
Meantime the attitude of the press is very curious and comical. The mayor's action is formally and half-heartedly "approved," but are the authorities of the county, and of the villages and small towns in Cook county, urged and admonished to follow Thompson's example and to enforce the Sunday law because it is law? By no means. The officials in the aforesaid places are doubtless perplexed, but the press is not anxious to come to their relief by any definite line of advice and reasoning. Furthermore, as ex-Mayor Harrison has reminded us in an anti-Thompson speech of a most incompromising kind, no newspaper has advocated the enforcement of the law imposing the general property tax on the ground that law is law and that the way to repeal a bad law is to enforce it strictly and to the letter. On the contrary; the disregard of that law has been generally applauded and defended.

The simple truth is, there is much cant and hollow pretense in the local treatment of the Sunday question. It is safe to say that the future of that question depends on the future of the Prohibition and anti-saloon movement. Facts and public sentiment will-as they should-determine future policy with reference to Sunday closing. The melodramatic and sensational antics of this or that big or little politician have their ephemeral interest, but important questions are not settled by cheap and erratic demagogues, any more than they are settled by dogmatic fanatics. Mayor Thompson is a symptom. His coup is a symptom. Soberminded citizens know that they have a real and difficult problem to solve in connection with the saloon and with Sunday recreation and amusement for the masses. The American saloon must be reformed; the poor man must have his "club"; substitutes must be found for the institutions we abolish because of their vileness or demoralization-or our last state may be worse than the first.

\title{
FIRE LIMITS DISTRICTS AND THEIR IM- PORTANCE
}

\author{
BY C. T. BISSELL ${ }^{1}$ \\ New York City
}

\begin{abstract}
A PERSON building a house in the country may have a right to jeopardize his own life and property and those of his family, and take chances with the companies selling indemnity against loss; but there is no question that the owner of property in a city or town has no right to erect a structure which will be a menace in case of fire to the safety of the property of the adjacent owner. The latter principle has long been recognized. It has been conjectured by some that the great fire in Rome of A.D. 64 was started by Nero's orders, for the purpose of

${ }^{1}$ Engineer, Committee on Fire Prevention, National Board of Fire Underwriters.
\end{abstract}

